\title{
PERANCANGAN SISTEM INFORMASI PENJUALAN BERBASIS WEB PADA RUMAH MAKAN NASI BEBEK SAKERA
}

\author{
DIAN GUSTINA, IVAN BIJAKSONO \\ UNIVERSITAS PERSADA INDONESIA Y.A.I
}

\begin{abstract}
ABSTRAK
Sekarang ini ketergantungan dan kebutuhan suatu perusahaan akan teknologi informasi makin meningkat, Rumah Makan Nasi Bebek Sakera memiliki 4 Cabang yang tersebar, ditambah Gudang penyimpanan Bahan Makanan yang terpisah dan juga Pemasok bahan Makan yang harus selalu terhubung yang membuat pengaturan pola penjualan harus di tingkatkan. Sehingga mempermudah untuk mengontrol Penjualan dan melihat Laporan dari hasil Penjualan. Dengan cangkupan usaha yang seluas itu, Manajer akan kesulitan untuk mengikuti tren penjualan. Untuk itu diperlukan adanya sistem yang mengatur keselurahan sehingga membuat permasalahan yang ada dapat terselesaikan. Sebelumnya Sistem Penjualan dillakukan secara manual dan Laporan keuangannya masih juga manual, dan ini sungguh memakan waktu dan tenaga. Tujuan penulis ialah membuat aplikasi dimana Proses Penjualan dan Laporan dapat secara realtime sehingga mempermudah tugas manajer serta pengguna lainnya. Dengan metode pengumpulan data dan analisa kebutuhan menghasilkan Aplikasi Penjualan Berbasis Web Pada Rumah Makan Nasi Bebek Sakera. Berdasarkan hasil uji coba yang dilakukan, aplikasi ini mempermudah pekerjaan Manajer serta membantu dan menunjang pekerjaan pengguna lainnya.

Kata kunci : Analisis, Sistem, Penjualan, Analisa Sistem Informasi Penjualan, Laporan Penjualan, Kasir, Kepala Produksi, Gudang.
\end{abstract}

\section{PENDAHULUAN}

Dalam era globalisasi dan teknologi yang semakin pesat ini, penggunaan komputer sebagai salah satu alat teknologi informasi sangat dibutuhkan keberadaannya hampir disetiap aspek kehidupan. Penggunaan perangkat komputer sebagai $\mathrm{p}$ erangkat pendukung manajemen dan pengolahan data sangat tepat dengan mempertimbangkan kuantitas dan kualitas data, dengan demikian penggunaan perangkat komputer dalam setiap informasi sangat mendukung sistem pengambilan keputusan.

Nasi Bebek Sakera adalah salah satu usaha yang bergerak di bidang penjualan makanan khas daerah Madura yang menjual nasi bebek sebagai menu andalan. Saat ini pencatatan atas transaksi pembelian dan penjualan perusahaan masih dilakukan secara manual dan bisa dikatakan kurang memadai melihat kenyataan transaksiyang terjadi relatif besar jumlahnya, sehingga agak menyita waktu bila ingin menghasilkan laporan persediaan dalam waktu singkat. Sudah saatnya perusahaan menerapkan sistem informasi penjualan secara komputerisasi yang berbasis web untuk mengatasi hal tersebut.

Untuk mengatasi atau mengantisipasi terjadinya kerusakan maupun kehilangan data, maka perlu dibuat suatu program atau sistem yang dapat menjaga 
keamanan data serta dapat menghasilkan suatu laporan yang diinginkan oleh perusahaan, sehingga jika data-data tersebut digunakan sewaktu-waktu maka sangatlah mudah untuk mendapatkannya dan tidak memakan waktu yang lama.

Sistem yang baik sangatlah dibutuhkan oleh perusahaan demi meningkatkan kemajuan perusahaan itu sendiri dan menghindari terjadinya berbagai masalah baik didalam maupun diluar perusahaan.

Oleh karena itu penulis mencoba menerapkan suatu program yang dapat membantu menyelesaikan masalah tersebut diatas dengan menuangkannya dalam Laporan Tugas Akhir dengan judul "Perancangan Sistem Informasi Penjualan Berbasis Web pada rumah makan Nasi bebek Sakera“ di Jakarta Timur.

\section{METODOLOGI}

Dalam pembuatan proposal Perancangan Sistem Informasi Penjualan Berbasis Web pada rumah makan Nasi bebek Sakera yang berletak di Jakarta Timur. Metodologi penelitian yang digunakan adalah Expert System Life Cycle (ESLC).

Kegiatan analisis merupakan kegiatan penguraian suatu sistem informasi yang utuh dan nyata ke dalam bagian-bagian atau komponen komputer dengan tujuan untuk mengindentifikasi serta mengevaluasi masalah yang muncul. Sehingga mengarah kepada suatu solusi untuk perbaikan maupun pengembangan teknologi.

Khususnnya bagi perusahaan Nasi Bebek Sakera.

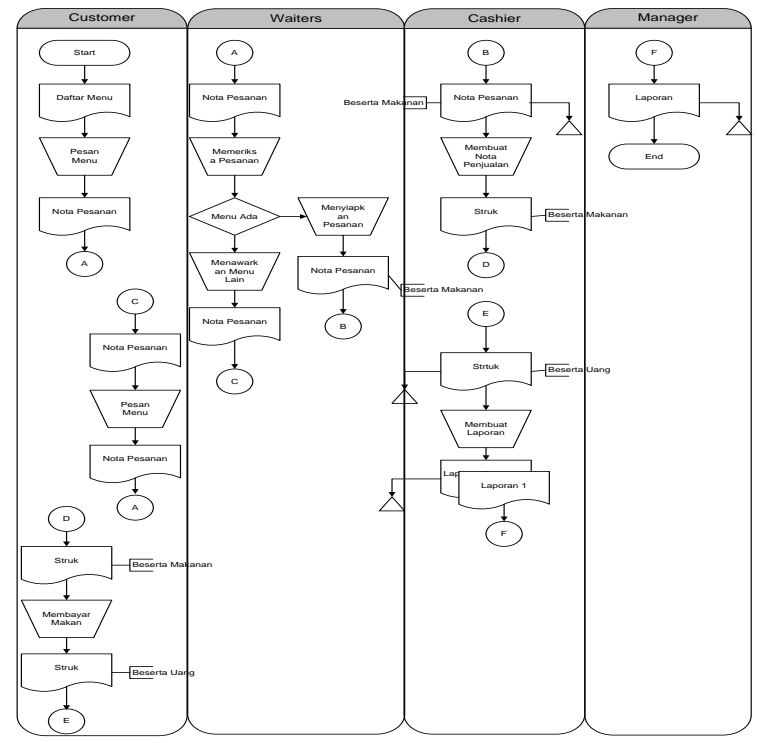

Gambar 1. Flow Chart : Sistem Transaksi Normal Nasbek

Pertama dimulai dari customer datang lalu melihat daftar menu kemudian pesan menu jika Menu tidak ada maka akan diganti dengan menu yang lain atau tidak jadi memesan.

Jika menu ada atau Customer memilih menu lain dan melanjutkan memesannya maka akan dicatat oleh waiters dan akan di berikan nota pembayaran. Nota pembayaran tersebut terbagi dua rangkap yang satu buat waiters dan yang satu lagi buat kasir. Nota yang diberikan kepada waiters akan di berikan kepada $\mathrm{K}$ sebagai patokan untuk membuat menu dan setelah itu akan di berikan kepada Cashier sebagai panutan jika terjadi kendala transaksi pembayaran.

Perancangan Model Sistem Informasi Penjualan Nasi Bebek Sakera berbasis Web : 


\section{a. Activity Diagram alur lengkap}

1) Use Case Diagram

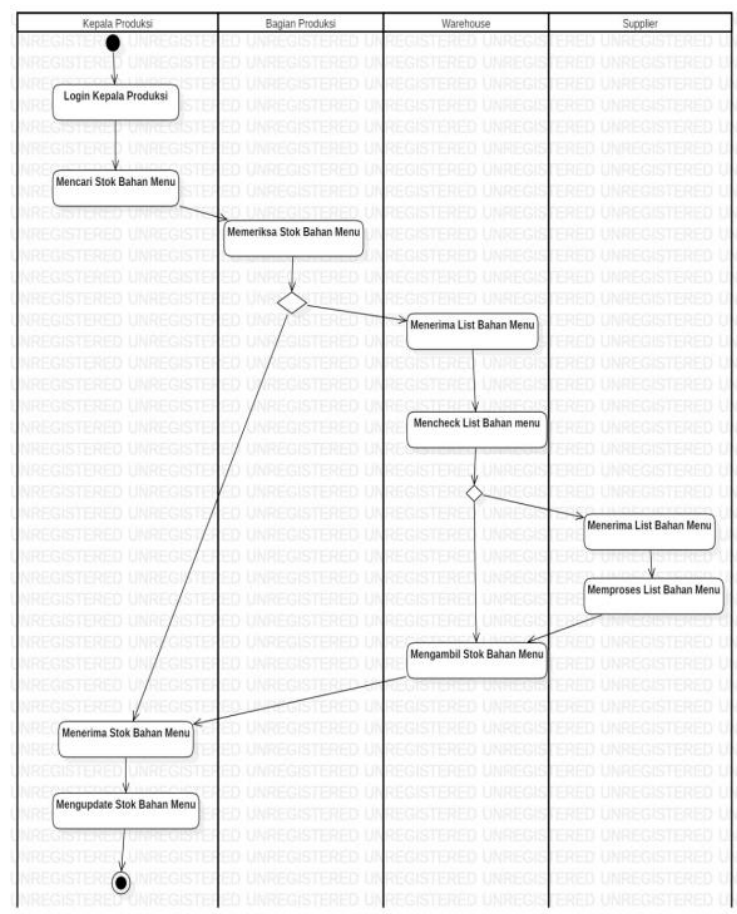

Gambar 2.Use Case perancangan model Take Away

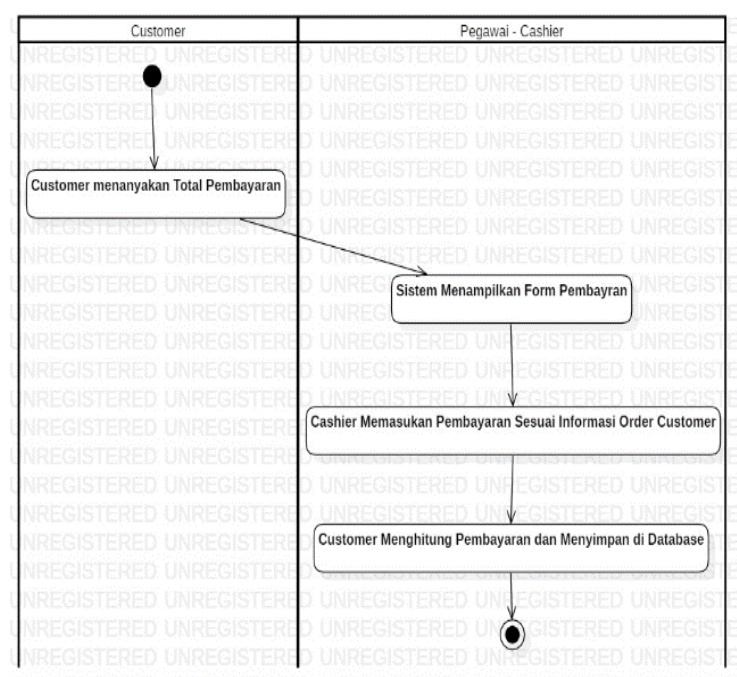

Gambar 3. Use Case 0.0 perancangan model

2) Activity Diagram

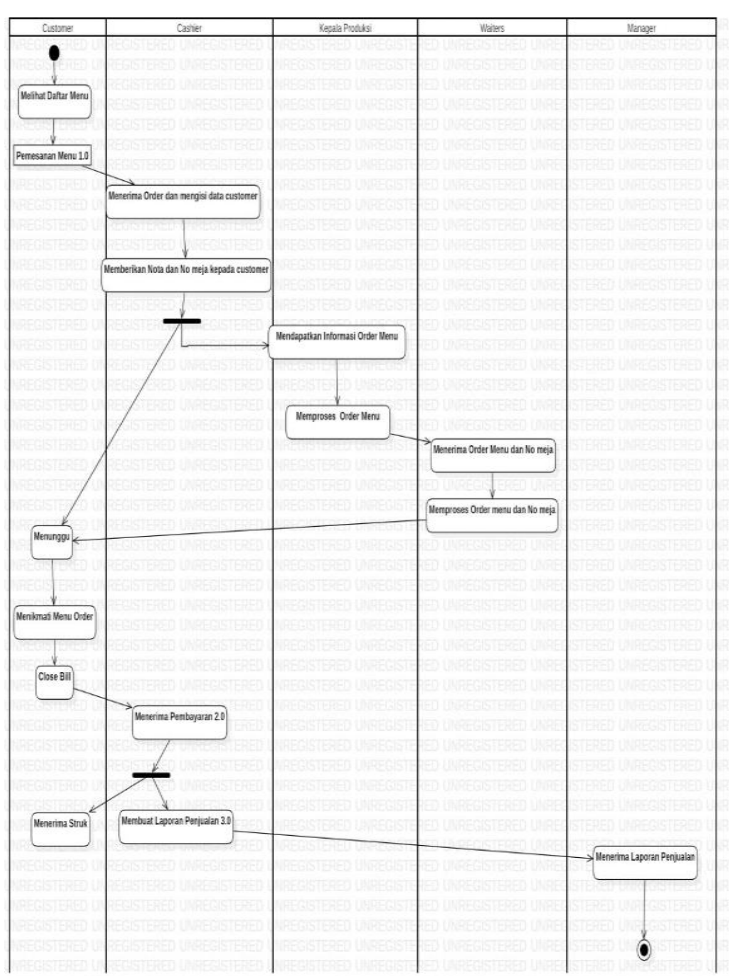

Gambar 4.Activity Diagram alur lengkap

b. Activity Diagram alur Pemilihan Paket Menu

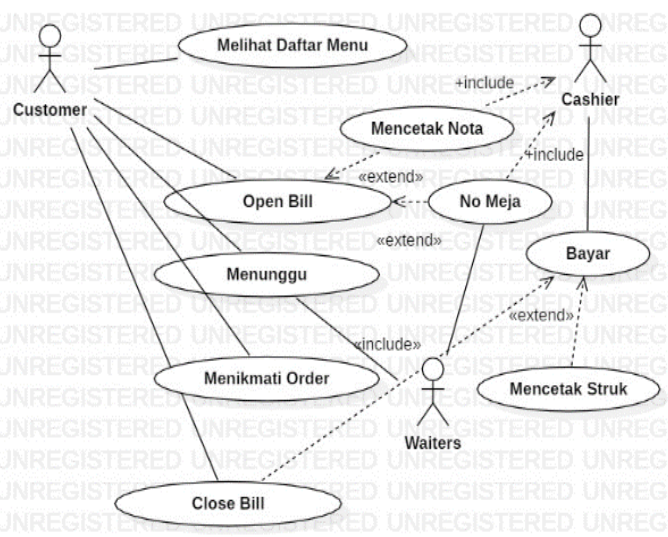

Gambar 5.Penjelasan Activity Diagram Alur Pemilihan Paket Menu 
3) Sequence Diagram

a. Login Manager

Ini adalah tata cara login Manager pada rumah makan nasi bebek sakera di semua cabang.
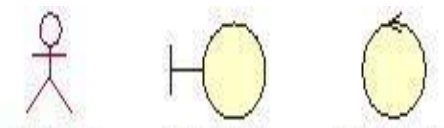

:Manager
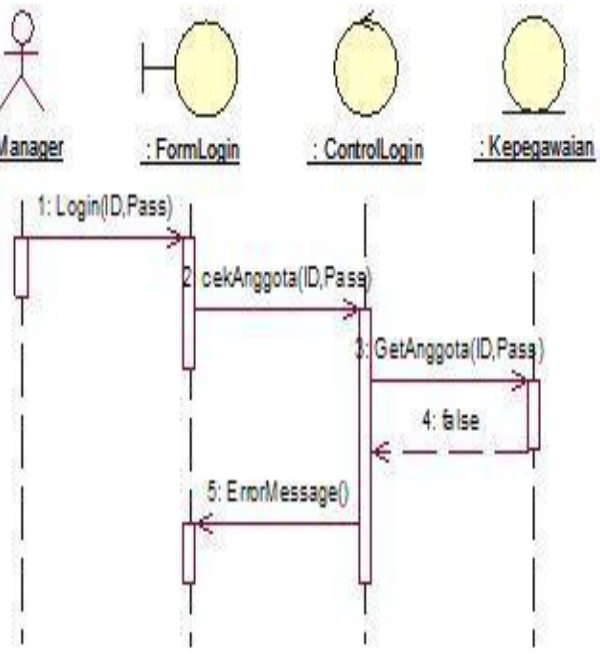

Gambar 6.Sequence Diagram Login Manager

b. Sequence Diagram Pembayaran Proses pembayaran transaksi oleh Pembeli (Customer) kepada kasir (Cashier) secara lengkap.
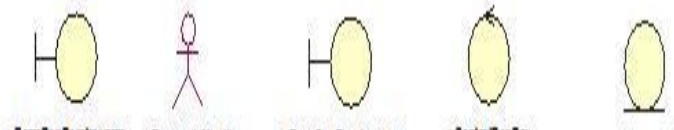

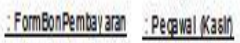
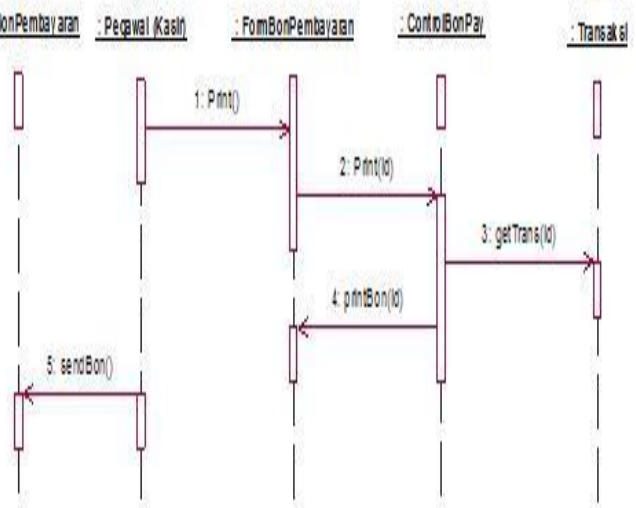

Gambar 7.Sequence Diagram Pembayaran

c. Sequence Diagram Mencetak Bukti Pembayaran

Proses serah terima bukti pembayaran oleh Kasir (Cashier) kepada Pembeli (Customer).

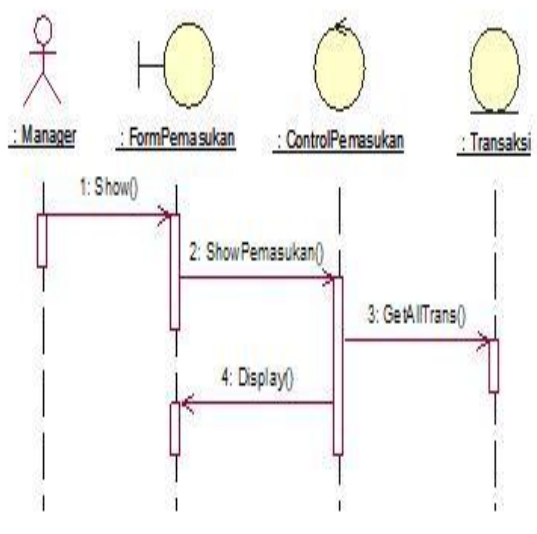

Gambar 8.Sequence Diagram mencetak bukti pembayaran

d. Sequence Diagram Manager mencheck Pemasukan

Berikut adalah aktivitas Manager untuk mencheck Pemasukan di Rumah makan Nasi Bebek Sakera.

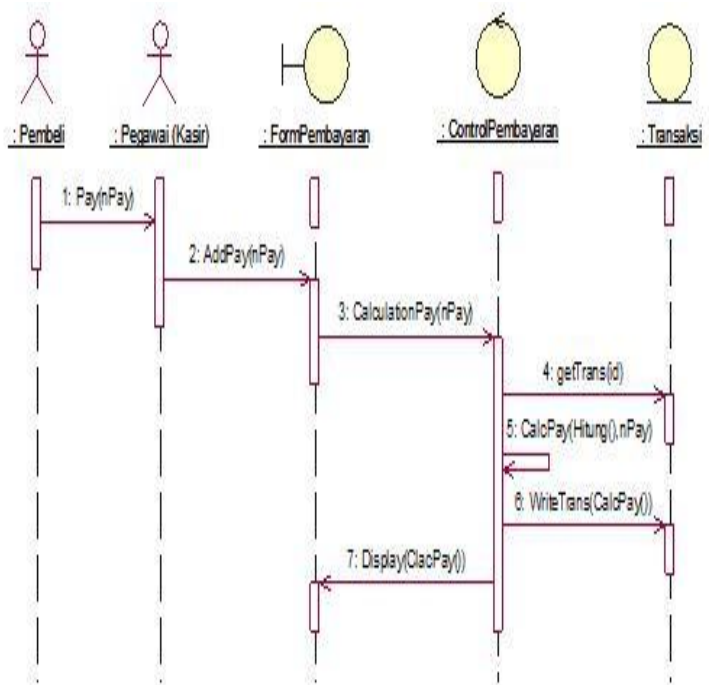


Gambar 9.Sequence Diagram

Manager Mengecek Laporan

e. Class Diagram Sistem Informasi Nasi Bebek Berjalan

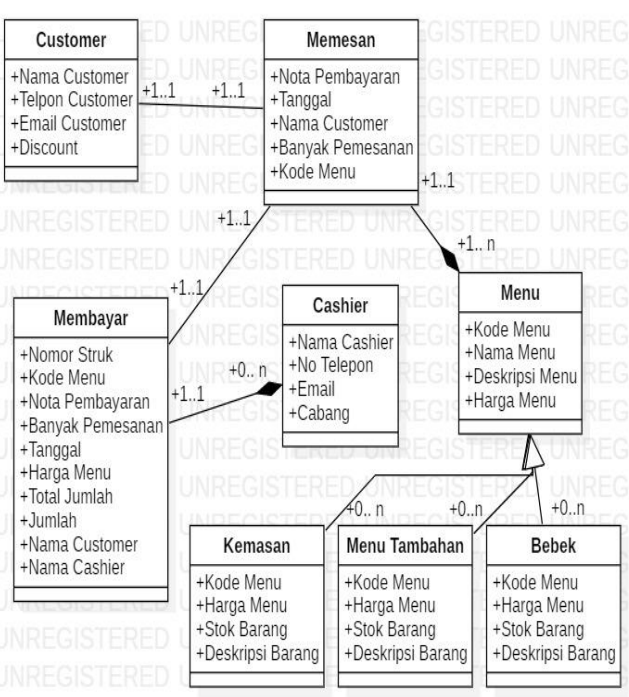

Gambar 10.Class Diagram Sistem Informasi Nasi Bebek Sakera

\section{Hierarchy Plus Input Process Output (HIPO)}

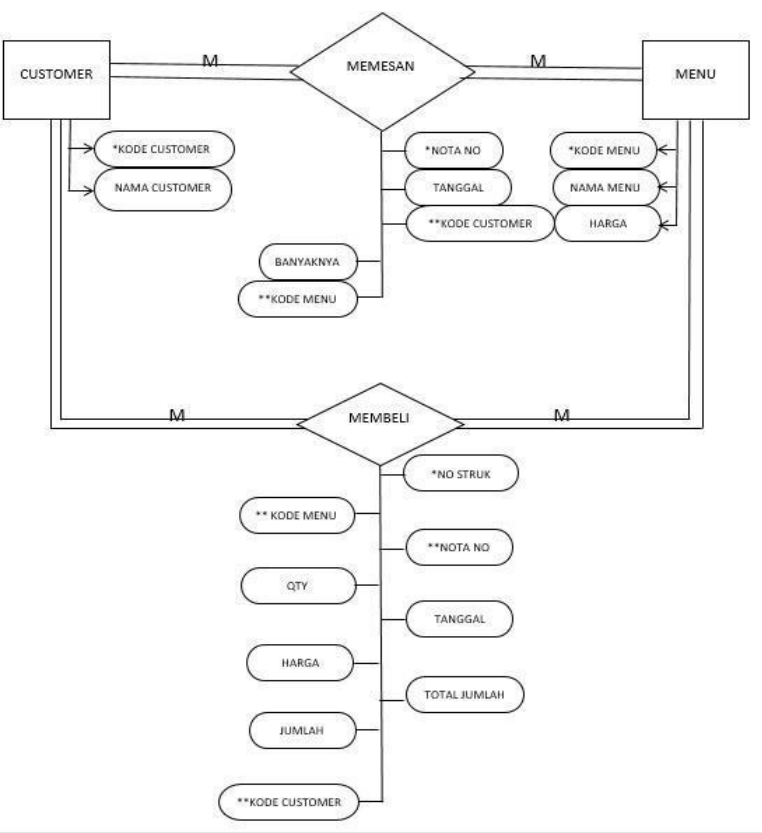

Gambar 11. HIPO perancangan model Nasi Bebek Sakera

Entity relationship Diagram (ERD)

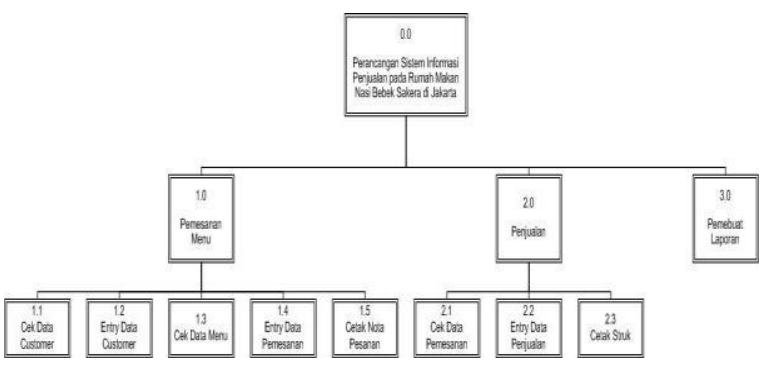

Gambar 12.ERD Nasi Bebek

Sakera

\section{PEMBAHASAN}

Penjelasan dan Cara Menjalankan Aplikasi Login.

Pada menu login dibawah, Yang dapat Login adalah User dalam kategori (Manager, Kepala Produksi, dan Cashier) bagaimana cara login. Beserta Tampilan gambar Favicon dari Web Nasi Bebek Sakera.

1) Favicon Web Nasi Bebek Sakera

$$
\text { POS Login }
$$

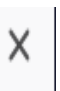

Gambar 13.Favicon Web Nasi Bebek Sakera

2) Login di dalam Web Nasi Bebek Sakera

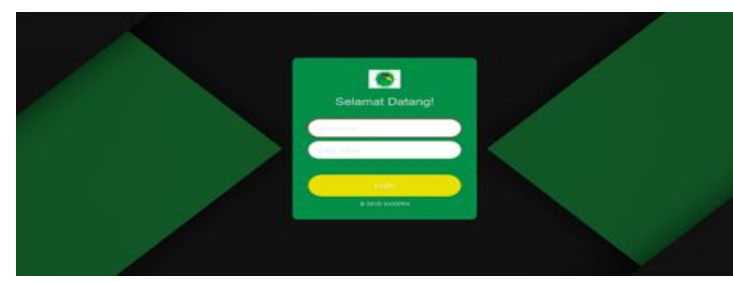

Gambar 14. Tampilan Menu Login Full 
Gambar 16. Menu Utama : Pemilihan

Cabang Nasi Bebek Sakera

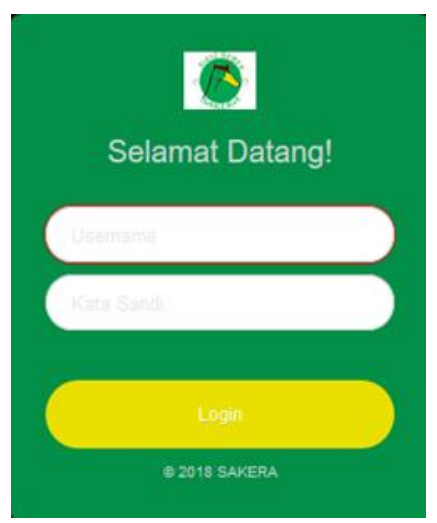

Gambar 15. Tampilan Menu Login Close Up

\section{Menu Utama}

Di menu utama, user dapat memilih Cabang Nasi Bebek Sakera yang ingin dia tuju. Khusus Cashier dan Kepala Produksi sudah otomatis masuk sesuai data diri.

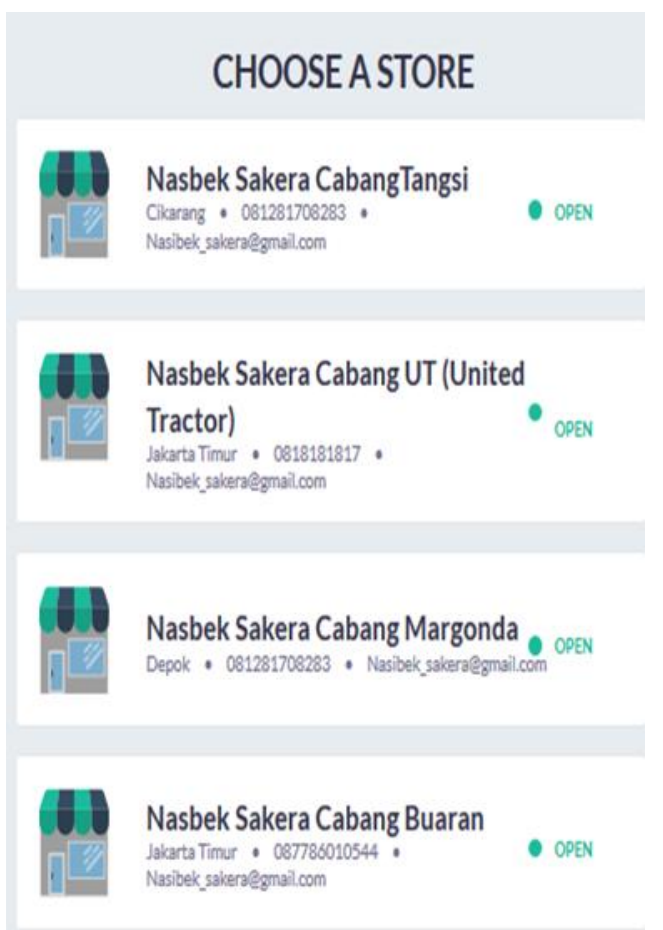

\section{Daftar Menu di Nasi Bebek Sakera}

Di dalam Daftar Menu ini adalah Point Of View Customer saat melihat Daftar Menu Nasi Bebek Sakera.

1) Daftar Menu Point Of View Customer

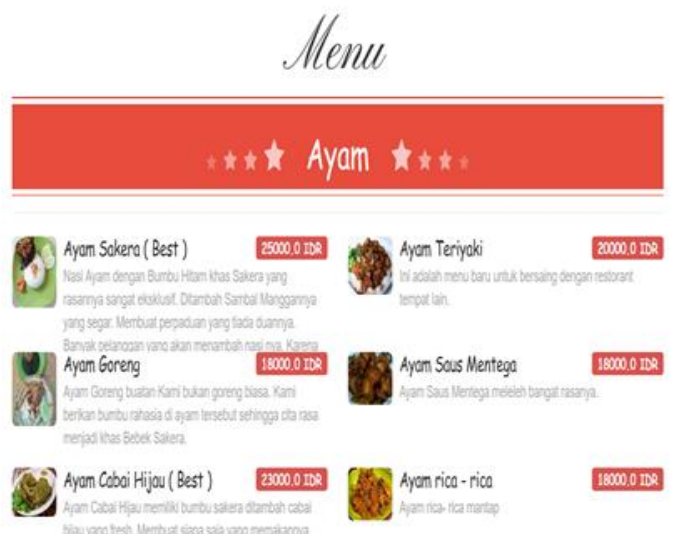

Gambar 17. Daftar Menu : Ayam

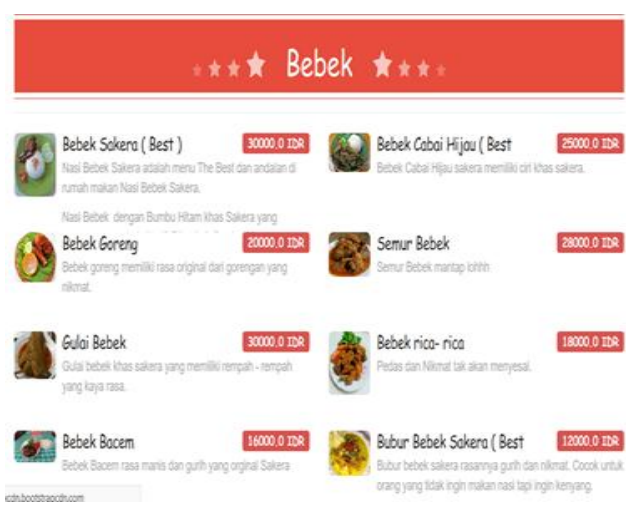

Gambar 18. Daftar Menu : Bebek

2) Daftar Menu Point Of View Cashier

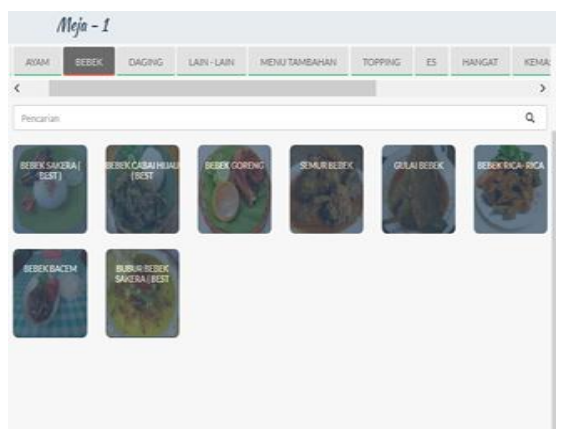


Gambar 19. Daftar Menu Point Of View Cashier

\section{Menu Part}

Didalam menu part ini, user dapat melihat pilihan yang tersedia khusus Manager

Title Bar Web Nasi Bebek Sakera

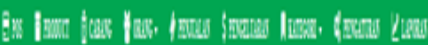

Gambar 20. Title Bar Web Nasi Bebek Sakera

Menu Open Bill dari Point Of View Cashier

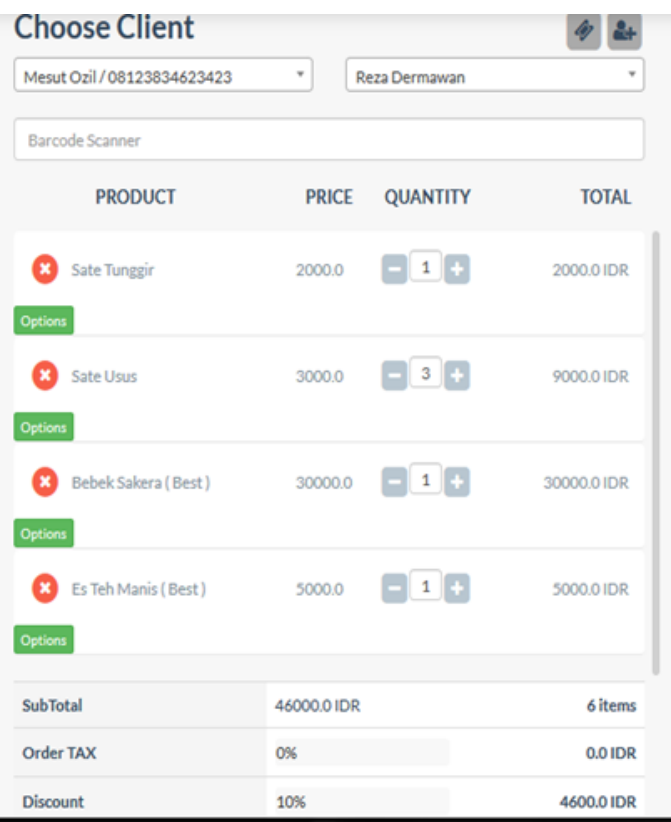

Gambar 21. Menu Open Bill Point Of View
Cashier 1

\begin{tabular}{llr}
\hline SubTotal & 460000 ODR & 6items \\
\hline OrderTAX & O\% & $0.010 R$ \\
\hline Discount & $10 \%$ & $4600.010 R$ \\
\hline Total & 414000 IDR & \\
\hline & & \\
\hline & & \\
\hline
\end{tabular}

Gambar 22. Menu Open Bill Point Of View Cashier 2

Didalam menu ini ditampilkan :

a) Customer tersebut apakah Customer Biasa (Walk In Customer) atau Member. Di dalam kasus ini Customer adalah Member dengan nama Mesut Ozil

b) Cashier yang melayani adalah Reza Dermawan.

c) Harga total sudah mendapatkan diskon sebesar $10 \%$.

Hasil akhir Close Bill dari Point Of View Customer (Struk)

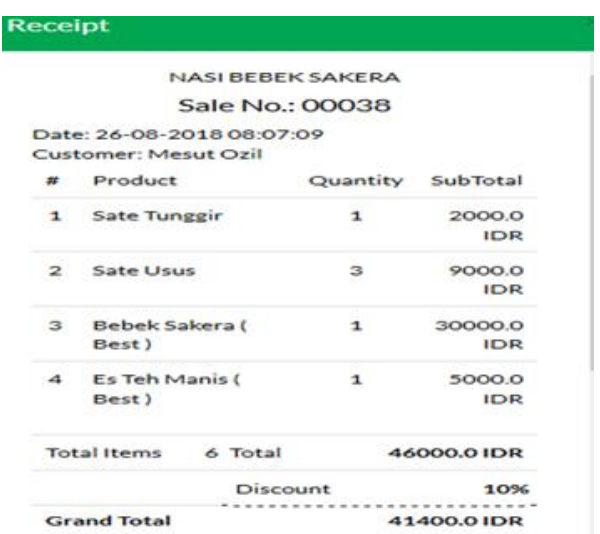


Gambar 23. Close Bill Point Of View Customer 1

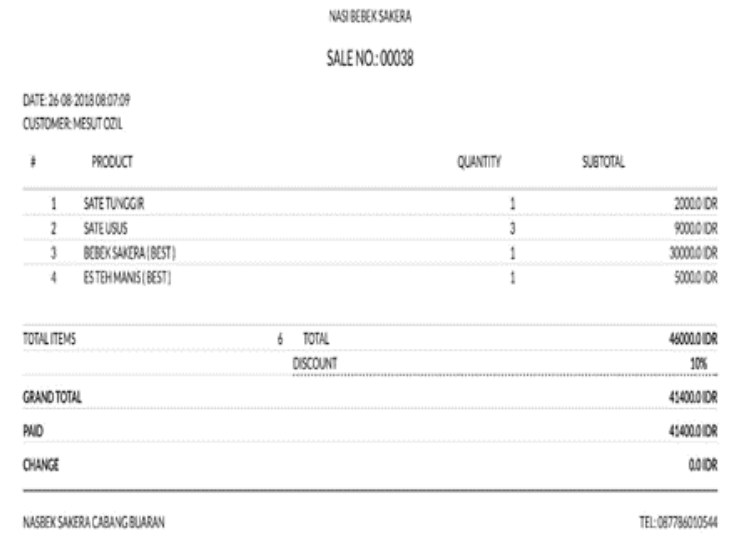

||||||||||||||||||||||

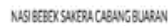

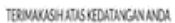

Gambar 24. Close Bill Point Of View Customer 2

Menu Laporan Penjualan Nasi Bebek Sakera

Disini Manager dapat melihat Laporan penjualan di Nasi Bebek Sakera, didalam menu ini ditampilkan :
a) Customer
: Dapat
melihat jumlah Customer yang mengunjungi Nasi Bebek Sakera
b) Product

c) Today Sale : Dapat melihat total penjualan hari ini

d) Grafik Bulanan : Dapat mengetahui Grafik Pendapatan dan Pengeluaran

e) Diagram : Dapat Melihat Lima Produk terlaku selama bulan ini

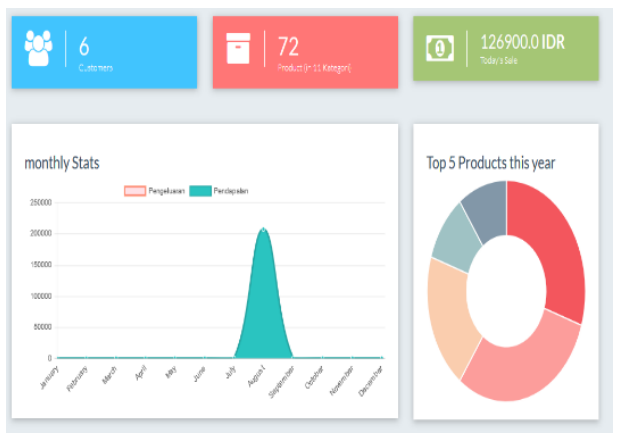

Gambar 25.Tampilan Laporan Manager

Tampilan Logout atau Exit Aplikasi Web Nasi Bebek Sakera

Disini User dapat melogout akunnya dengan mengclick simbol di bawah ini.

\section{Ivan Bijaksono}

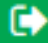

Gambar 26. Tampilan Logout

Testing Aplikasi

Setelah dilakukan implementasi, maka perlu diketahui apakah aplikasi berjalan dengan benar. Maka itu dilakukan pengujian program pada tabel 4.1 pengujian aplikasi.

Tabel 1. Pengujian Aplikasi Web Nasi Bebek Sakera

\begin{tabular}{|l|l|l|l|l|}
\hline No. & Fungsi & Cara Pengujian & Yang Diharapkan & Kesimpulan \\
\hline
\end{tabular}




\begin{tabular}{|c|c|c|c|c|}
\hline 1. & $\begin{array}{l}\text { Login } \\
\text { Manager }\end{array}$ & $\begin{array}{l}\text { Manager login dengan } \\
\text { mengisi username dan } \\
\text { kata sandi. }\end{array}$ & $\begin{array}{l}\text { Sukses login } \\
\text { kedalam aplikasi } \\
\text { dan menampilkan } \\
\text { menu utama. }\end{array}$ & $\mathrm{OK}$ \\
\hline 2. & Menu Utama & $\begin{array}{l}\text { User memilih Cabang } \\
\text { yang ingin di lihat. }\end{array}$ & $\begin{array}{l}\text { User dapat melihat } \\
\text { detail Cabang } \\
\text { secara keseluruhan }\end{array}$ & $\mathrm{OK}$ \\
\hline 3. & $\begin{array}{l}\text { Daftar Menu di } \\
\text { Nasi Bebek } \\
\text { Sakera }\end{array}$ & $\begin{array}{l}\text { Customer memilih } \\
\text { menu, apakah } \\
\text { tampilannya benar dan } \\
\text { sesuai dengan } \\
\text { deskripsi yang di } \\
\text { tampilkan }\end{array}$ & $\begin{array}{l}\text { Dapat melihat } \\
\text { Menu dan } \\
\text { Deskripsi. }\end{array}$ & OK \\
\hline 4. & Menu Part & $\begin{array}{l}\text { Manager melihat atau } \\
\text { mengubah detail yang } \\
\text { di inginkan }\end{array}$ & $\begin{array}{l}\text { User dapat } \\
\text { menambahkan atau } \\
\text { mengurangi } \\
\text { Pegawai atau } \\
\text { Supplier }\end{array}$ & $\mathrm{OK}$ \\
\hline 5. & $\begin{array}{l}\text { Menu Member } \\
\text { Customer }\end{array}$ & $\begin{array}{l}\text { User dapat mengubah } \\
\text { Customer yang } \\
\text { dinginkan }\end{array}$ & $\begin{array}{l}\text { Member Customer } \\
\text { Terdata dan dapat } \\
\text { digunakan }\end{array}$ & $\mathrm{OK}$ \\
\hline 6. & $\begin{array}{l}\text { Menu Open } \\
\text { Bill Cashier }\end{array}$ & $\begin{array}{l}\text { User mengoperasikan } \\
\text { Sesuai Order }\end{array}$ & $\begin{array}{l}\text { User dapat melihat } \\
\text { semua Menu yang } \\
\text { tersedia dimasing- } \\
\text { masing lokasi. }\end{array}$ & OK \\
\hline 7. & $\begin{array}{l}\text { Menu Laporan } \\
\text { Penjualan }\end{array}$ & $\begin{array}{l}\text { User dapat } \\
\text { mengoperasikan sesuai } \\
\text { dengan kehendaknya. }\end{array}$ & $\begin{array}{l}\text { User dapat melihat } \\
\text { berbagai daftar } \\
\text { statistik dari } \\
\text { Penjualan. }\end{array}$ & $\mathrm{OK}$ \\
\hline
\end{tabular}

LAPORAN HASIL KUISIONER

\begin{tabular}{|c|c|c|c|c|c|c|c|c|c|c|c|c|c|}
\hline \multirow{2}{*}{$\begin{array}{c}\text { No } \\
\text {. }\end{array}$} & \multirow[b]{2}{*}{ Pertanyaan } & \multirow{2}{*}{$\begin{array}{c}\text { Jawaba } \\
\mathrm{n}\end{array}$} & \multicolumn{10}{|c|}{ Responden } & \multirow[b]{2}{*}{ Hasil } \\
\hline & & & 1 & 2 & 3 & 4 & 5 & 6 & 7 & 8 & 9 & $\begin{array}{l}1 \\
0\end{array}$ & \\
\hline \multirow{4}{*}{1} & \multirow{4}{*}{$\begin{array}{l}\text { Ukuran huruf yang } \\
\text { digunakan sudah } \\
\text { nyaman dibaca }\end{array}$} & SS & 1 & 1 & 1 & & & 1 & & 1 & 1 & 1 & 7 \\
\hline & & $S$ & & & & 1 & 1 & & 1 & & & & 3 \\
\hline & & TS & & & & & & & & & & & 0 \\
\hline & & STS & & & & & & & & & & & 0 \\
\hline 2 & $\begin{array}{l}\text { Tata letak jendela, } \\
\text { tulisan, gambar dll }\end{array}$ & SS & 1 & 1 & 1 & & & 1 & 1 & 1 & 1 & 1 & 8 \\
\hline
\end{tabular}




\begin{tabular}{|c|c|c|c|c|c|c|c|c|c|c|c|c|c|}
\hline & \multirow{3}{*}{$\begin{array}{c}\text { sudah baik dan } \\
\text { serasi }\end{array}$} & $S$ & & & & 1 & 1 & & & & & & 2 \\
\hline & & $\mathrm{TS}$ & & & & & & & & & & & 0 \\
\hline & & STS & & & & & & & & & & & 0 \\
\hline \multirow{4}{*}{3} & \multirow{4}{*}{$\begin{array}{l}\text { Komposisi warna } \\
\text { untuk huruf, latar } \\
\text { belakang, gambar, } \\
\text { dll sudah baik dan } \\
\text { serasi }\end{array}$} & SS & 1 & 1 & 1 & & 1 & 1 & & 1 & 1 & 1 & 8 \\
\hline & & $\mathrm{S}$ & & & & 1 & & & 1 & & & & 2 \\
\hline & & $\mathrm{TS}$ & & & & & & & & & & & 0 \\
\hline & & STS & & & & & & & & & & & 0 \\
\hline \multirow{4}{*}{4} & \multirow{4}{*}{$\begin{array}{l}\text { Perintah-perintah } \\
\text { yang ada mudah } \\
\text { dipahami }\end{array}$} & SS & 1 & & & 1 & & & 1 & 1 & 1 & & 5 \\
\hline & & $S$ & & & & & & 1 & & & & 1 & 2 \\
\hline & & TS & & 1 & 1 & & 1 & & & & & & 3 \\
\hline & & STS & & & & & & & & & & & 0 \\
\hline \multirow{4}{*}{5} & \multirow{4}{*}{$\begin{array}{l}\text { Informasi yang } \\
\text { ada pada tiap } \\
\text { tampilan mudah } \\
\text { dipahami }\end{array}$} & SS & & 1 & 1 & 1 & & 1 & 1 & & 1 & & 6 \\
\hline & & $S$ & 1 & & & & 1 & & & 1 & & 1 & 4 \\
\hline & & $\mathrm{TS}$ & & & & & & & & & & & 0 \\
\hline & & STS & & & & & & & & & & & 0 \\
\hline \multirow{4}{*}{6} & \multirow{4}{*}{$\begin{array}{l}\text { Sistem ini mudah } \\
\text { saya operasikan } \\
\text { meskipun tanpa } \\
\text { panduan ataupun } \\
\text { pelatihan }\end{array}$} & SS & & & & & & & & & & & 0 \\
\hline & & $S$ & & & 1 & & 1 & 1 & 1 & 1 & 1 & 1 & 7 \\
\hline & & TS & 1 & 1 & & 1 & & & & & & & 3 \\
\hline & & STS & & & & & & & & & & & 0 \\
\hline \multirow{4}{*}{7} & \multirow{4}{*}{$\begin{array}{l}\text { Aplikasi relevan } \\
\text { dengan kebutuhan } \\
\text { dilapangan }\end{array}$} & SS & 1 & 1 & 1 & 1 & 1 & 1 & 1 & 1 & 1 & 1 & 10 \\
\hline & & $\mathrm{S}$ & & & & & & & & & & & 0 \\
\hline & & $\mathrm{TS}$ & & & & & & & & & & & 0 \\
\hline & & STS & & & & & & & & & & & 0 \\
\hline \multirow{4}{*}{8} & \multirow{4}{*}{$\begin{array}{c}\text { Aplikasi } \\
\text { membantu } \\
\text { pekerjaan saya }\end{array}$} & SS & 1 & 1 & 1 & 1 & & 1 & 1 & & 1 & & 7 \\
\hline & & $S$ & & & & & 1 & & & 1 & & 1 & 3 \\
\hline & & TS & & & & & & & & & & & 0 \\
\hline & & STS & & & & & & & & & & & 0 \\
\hline \multirow{4}{*}{9} & \multirow{4}{*}{$\begin{array}{l}\text { Informasi yang } \\
\text { dihasilkan sesuai } \\
\text { dengan kebutuhan }\end{array}$} & SS & 1 & & & & & 1 & 1 & 1 & & & 4 \\
\hline & & $S$ & & 1 & 1 & 1 & & & & & 1 & 1 & 5 \\
\hline & & $\mathrm{TS}$ & & & & & 1 & & & & & & 1 \\
\hline & & STS & & & & & & & & & & & 0 \\
\hline \multirow{2}{*}{10} & \multirow{2}{*}{$\begin{array}{c}\text { Aplikasi } \\
\text { mempercepat }\end{array}$} & SS & 1 & 1 & 1 & & 1 & 1 & 1 & 1 & 1 & 1 & 9 \\
\hline & & $S$ & & & & 1 & & & & & & & 1 \\
\hline
\end{tabular}




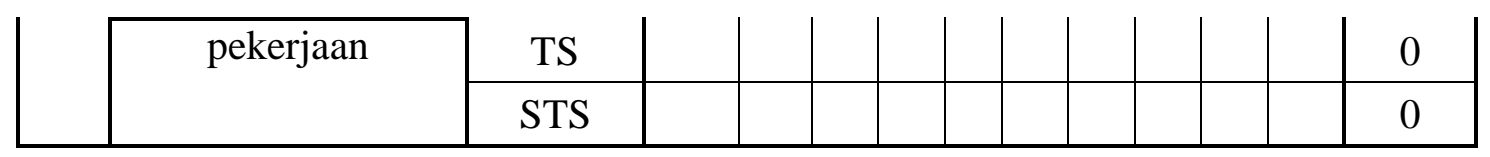

$[($ Baik Sekali x 5) $+($ Baik x 4) $+($ Cukup x 3) $+($ Buruk x 2$)+($ Buruk Sekali $x$ 1)] $=$ Nilai

\begin{tabular}{|c|r|r|r|}
\multicolumn{1}{l}{$\begin{array}{l}\text { nilai rata: } \\
\text { nilai akhir: }\end{array}$} & \multicolumn{3}{l}{$\begin{array}{l}\text { nilai/jumlah user } \\
\text { total nilai rata2/jumlah } \\
\text { soal }\end{array}$} \\
\hline & \multicolumn{1}{|c|}{ Total } & $\begin{array}{c}\text { Ka } \\
\text { li }\end{array}$ & Hasil \\
\hline & 64 & 4 & 256 \\
\hline SS & 29 & 3 & 87 \\
\hline S & 7 & 2 & 14 \\
\hline TS & 0 & 1 & 0 \\
\hline STS & \multicolumn{2}{|c|}{ Nilai } & 357 \\
\hline & $\begin{array}{l}\text { Nilai Rata- } \\
\text { rata: } \\
\end{array}$ & $\begin{array}{l}\text { Niai Akhir: } \\
\text { Kesimpulan: }\end{array}$ & 35,7 \\
& Baik
\end{tabular}

\section{KESIMPULAN}

Berdasarkan pengujian yang telah dilakukan, maka dapat diambil kesimpulan terhadap pengembangan Aplikasi pada Rumah Makan Nasi Bebek Sakera Berbasis Web sebagai berikut:

1) Aplikasi ini dapat membantu Pekerjaan khsusnnya Manager, Supervisor, Cashier, dan Kepala Produksi dalam melakukan tugas mereka masing - masing.

2) Dengan perpindahan secara realtime, dapat membantu User menjalankan tugasnnya masing - masing.

3) Perpindahan realtime juga membuat Stok Bahan Menu (Makanan dan Minuman) dapat terdata dengan pasti. Sehingga mengurangi human error.
4) Transaksi sudah menggunakan cara modern sehingga pendapatan dari hasil penjualan dapat di pastikan.

\section{DAFTAR PUSTAKA}

[1] Munawar, 2005. Pemodelan Visual dengan UML. Jakarta. Garaha Ilmu.

[2] Nugroho, Bunafit, 2007. Trik dan Rahasia Mmebuat Aplikasi Web dengan PHP. Yogyakarta: Gaya Media Jogjakarta.

[3] 2008. Latihan Membuat Aplikasi Web PHP dan MySQL dengan Dreamweaver MX $6,7,2004)$ dan 8. Yogyakarta: Gaya Media Jogjakarta. 
[4] Sukarno, Haris, 2006.Membangun Website Dinamis Interaktif dengan PHP-MySQL (Windows \& Linux). Jakarta: Eksa Media.
[5] Gunawan, Wahyu. Kebut Sehari Jadi Master PHP. Yogyakarta: Genius Publisher, 2010. 